Article

\title{
Effects of Seedling Quality and Family on Performance of Northern Red Oak Seedlings on a Xeric Upland Site
}

\author{
Cornelia C. Pinchot ${ }^{1, *}$, Thomas J. Hall ${ }^{2}$, Arnold M. Saxton ${ }^{3}$, Scott E. Schlarbaum ${ }^{4}$ and \\ James K. Bailey ${ }^{5}$ \\ USDA Forest Service, Northern Research Station, Delaware, OH 43015, USA \\ Pennsylvania Bureau of Forestry, Harrisburg, PA 17105, USA; thall@pa.gov \\ Department of Animal Science, The University of Tennessee, Knoxville, TN 37996, USA; asaxton@utk.edu \\ 4 Department of Forestry, Wildlife, and Fisheries, The University of Tennessee, Knoxville, TN 37996, USA; \\ tenntip@utk.edu \\ 5 Pennsylvania Bureau of Forestry, Harrisburg, PA 17105, USA; acornsbailey@verizon.net \\ * Correspondence: corneliapinchot@fs.fed.us; Tel.: +1-740-368-0039
}

Received: 2 May 2018; Accepted: 11 June 2018; Published: 13 June 2018

\begin{abstract}
Cultural practices to develop larger, more robust oak seedlings have been developed, however, the potential improvement conferred by these larger seedlings has received limited testing in the Northeast. We evaluated the effect of seedling size and pedigree on the survival, growth, and competitive ability of northern red oak (Quercus rubra L.) seedlings planted on a xeric site in northeastern Pennsylvania. We planted seedlings from a state tree nursery that represented locally available seedling stock, as well as high-quality seedlings from seven half-sibling families grown following improved nursery protocol. Half-sibling families were split into three size classes based on their root collar diameter and height; large, average, and poor. Eleven years after planting, survival across seedling treatments ranged from 45 percent for locally available seedlings, to 96 percent for one half-sibling family. Two families showed superior growth, survival, and competitive ability compared with the others. Seedling size class conferred moderate height and diameter advantage in four and three of the families, respectively. Initial seedling size was an important variable in models predicting survival, diameter, and dominance (competitive ability). Over time, the relationship between initial diameter and height diminished.
\end{abstract}

Keywords: northern red oak; Quercus; Quercus rubra; artificial regeneration; seedling quality

\section{Introduction}

Oak (Quercus spp. L.) is an important genus throughout much of the Northern Hemisphere, though its abundance has declined in recent years, largely due to regeneration failures [1,2] caused by changes to disturbance regimes [3,4], browsing by white tailed deer (Odocoileus virginianus Zimmerman) [5], fire suppression [6,7] and interference from invasive plant species [8]. A robust field of research focusing on silvicultural methods for increasing oak advance regeneration has developed to address these declines, e.g., $[9,10]$. In the central Appalachians, shelterwood and midstory removal treatments, prescribed fire, and control of interfering vegetation, often in tandem with control of browsing, have been found to successfully encourage establishment of oak regeneration [11,12].

The presence of competitive oak seedlings, saplings and/or sprouts before a harvest is a critical requirement for successful regeneration of oak post-treatment $[13,14]$. Where adequate advance reproduction of oak is lacking, artificial regeneration can be a useful tool to meet stocking goals. Establishment success of planted oak into forested stands, however, has been variable, with failures 
caused by poor seedling quality [10], competition from fast growing species [4,15,16], moisture stress associated with transplant shock [17], browsing by deer [18,19], and lack of genetically improved planting stock [20].

The importance of seedling size to early survival and growth in northern red oak (Quercus rubra L.) has been well studied [10,21-28]. Larger oak seedlings tend to have larger root systems, which provide carbohydrates, water, and nutrients necessary to promote rapid growth, a key trait for competing with fast-growing seedlings and sprouts [10,29]. Cultural practices to develop larger, more robust oak seedlings have been developed [30], however, improvement conferred by these larger seedlings has received limited testing, most occurring on mesic sites in the southeastern U.S. [24,31,32]. Early testing (<8 years) suggests that using high-quality seedlings (sensu [30]) produced through advanced irrigation and fertilization protocols yields improved growth and competitive ability of northern red oak when planted in previously harvested stands [24,31,32]. However, the use of seedlings produced using these protocols has not been tested in xeric stands in the Northeast. While oak is easier to naturally regenerate on drier as compared with more productive sites, the presence of fast growing red maple (Acer rubrum L.) and birch (Betula spp. L.) often limits successful oak recruitment on xeric sites [33]. High-quality seedlings may be able to compete with fast-growing advance reproduction on such sites, offering a management alternative where oak regeneration is lacking. To test this, we compared the survival, growth, and competitive ability among varying size classes and families of northern red oak seedlings planted on a xeric site in northeastern Pennsylvania. Because there are a limited number of studies using high-quality northern red oak seedlings that also include an assessment of family-origin effects on establishment success [34], we also included a family treatment.

\section{Materials and Methods}

\subsection{Experimental Material}

Acorns from seven open-pollinated northern red oak mother trees, kept separate by pedigree, and a bulked collection were used in this study. The acorns from the half-sibling families were harvested from mother trees located in natural forest stands at the United States Military Academy Reservation, West Point, NY, and proximal area in the fall of 2003. Mother trees were located at least $0.40 \mathrm{~km}$ apart to avoid collecting closely related material. Acorns were sown in separate family seed lots in one nursery bed at the Georgia Forestry Commission's Flint River Nursery in Byromville, GA in December, 2003 at a density of 65 seeds per $\mathrm{m}^{2}$. Families were not replicated within the nursery bed. Fertilization and irrigation schedules followed guidelines developed by Kormanik and others [30] and were designed to produce high-quality seedlings. The seedlings were grown without root-pruning or top-clipping protocols. The one year (1-0) half-sibling seedlings were lifted in late January, 2005, transported to Knoxville, TN, USA, and placed in cold storage $\left(\sim 1^{\circ} \mathrm{C}\right)$. Total height and root collar diameter of each seedling were measured, and an individual identification tag was attached to each seedling. All half-sibling seedlings were visually sorted into three size classes within each family; small, average, and large; according to height and root collar diameter (sensu [35]); (Tables 1 and 2). We used the minimum root collar diameter $(8-10 \mathrm{~mm}$, [36]) recommended for northern red oak seedlings as the standard for our average seedling size class. Acorns for the treatment representing locally available seedlings were collected from multiple mother trees across the Ridge and Valley region of Pennsylvania and planted at a density of approximately 190 acorns per $\mathrm{m}^{2}$ at the Penn Nursery in Spring Mills, PA, USA. Seedlings were grown for one year and 1-0 bare-root seedlings were lifted in the spring of 2005 and kept in cold storage until they were transported to the study site for planting. These seedlings are termed "locally available" throughout the paper, represent seedlings available to landowners and forest managers in the Northeast at the time of the study, and are compared with the high-quality seedlings produced using advanced nursery protocol (sensu [30]). 
Table 1. Mean height ( \pm standard error) of families and seedling size classes within family at planting and eleven years after planting. LA indicates locally available seedlings. Means among families for family treatment and within family for size class (family) treatment with the same letters do not differ statistically $(\alpha=0.05)$.

\begin{tabular}{|c|c|c|c|c|c|}
\hline Family & $\begin{array}{l}\text { Family Height } \\
\text { at Planting } \\
(\mathrm{cm})\end{array}$ & $\begin{array}{l}\text { Family Height } \\
\text { after } 11 \text { Years } \\
(\mathrm{cm})\end{array}$ & $\begin{array}{c}\text { Size Class } \\
\text { within Family }\end{array}$ & $\begin{array}{c}\text { Size Class } \\
\text { Height at } \\
\text { Planting }(\mathrm{cm})\end{array}$ & $\begin{array}{c}\text { Size Class } \\
\text { Height after } \\
11 \text { Years }(\mathrm{cm})\end{array}$ \\
\hline \multirow{3}{*}{8} & \multirow{3}{*}{$50 \pm 2 C$} & \multirow[t]{3}{*}{$406 \pm 13 \mathrm{~A}$} & Small & $38 \pm 4 C$ & $401 \pm 25 \mathrm{~A}$ \\
\hline & & & Average & $51 \pm 3 \mathrm{~B}$ & $391 \pm 18 \mathrm{~A}$ \\
\hline & & & Large & $62 \pm 3 \mathrm{~A}$ & $426 \pm 45 \mathrm{~A}$ \\
\hline \multirow{3}{*}{9} & \multirow{3}{*}{$42 \pm 1 \mathrm{E}$} & \multirow[t]{3}{*}{$322 \pm 10 \mathrm{~B}$} & Small & $37 \pm 2 \mathrm{~B}$ & $302 \pm 12 \mathrm{~B}$ \\
\hline & & & Average & $44 \pm 2 \mathrm{~A}$ & $303 \pm 13 B$ \\
\hline & & & Large & $44 \pm 3 \mathrm{~A}$ & $360 \pm 18 \mathrm{~A}$ \\
\hline \multirow{3}{*}{10} & \multirow{3}{*}{$44 \pm 1 \mathrm{DE}$} & \multirow[t]{3}{*}{$319 \pm 10 \mathrm{BC}$} & Small & $40 \pm 2 B$ & $282 \pm 12 C$ \\
\hline & & & Average & $43 \pm 2 B$ & $318 \pm 14 \mathrm{~B}$ \\
\hline & & & Large & $50 \pm 2 \mathrm{~A}$ & $358 \pm 14 \mathrm{~A}$ \\
\hline \multirow{3}{*}{11} & \multirow{3}{*}{$57 \pm 1 \mathrm{~B}$} & \multirow[t]{3}{*}{$320 \pm 10 \mathrm{BC}$} & Small & $48 \pm 2 \mathrm{~B}$ & $236 \pm 16 C$ \\
\hline & & & Average & $52 \pm 2 \mathrm{~B}$ & $329 \pm 15 \mathrm{~B}$ \\
\hline & & & Large & $72 \pm 2 \mathrm{~A}$ & $394 \pm 13 \mathrm{~A}$ \\
\hline \multirow{3}{*}{12} & \multirow{3}{*}{$44 \pm 1 \mathrm{DE}$} & \multirow[t]{3}{*}{$306 \pm 12 \mathrm{BC}$} & Small & $36 \pm 2 \mathrm{~B}$ & $302 \pm 17 \mathrm{~A}$ \\
\hline & & & Average & $46 \pm 2 \mathrm{~A}$ & $289 \pm 17 \mathrm{~A}$ \\
\hline & & & Large & $50 \pm 3 \mathrm{~A}$ & $328 \pm 17 \mathrm{~A}$ \\
\hline \multirow{3}{*}{14} & \multirow{3}{*}{$46 \pm 2 \mathrm{CD}$} & \multirow[t]{3}{*}{$295 \pm 13 \mathrm{CD}$} & Small & $39 \pm 3 \mathrm{~B}$ & $275 \pm 20 \mathrm{~B}$ \\
\hline & & & Average & $43 \pm 2 B$ & $212 \pm 17 C$ \\
\hline & & & Large & $56 \pm 4 \mathrm{~A}$ & $397 \pm 22 \mathrm{~A}$ \\
\hline \multirow{3}{*}{16} & \multirow{3}{*}{$64 \pm 2 \mathrm{~A}$} & \multirow[t]{3}{*}{$377 \pm 14 \mathrm{~A}$} & Small & $45 \pm 4 C$ & $348 \pm 25 \mathrm{~A}$ \\
\hline & & & Average & $61 \pm 3 \mathrm{~B}$ & $408 \pm 21 \mathrm{~A}$ \\
\hline & & & Large & $87 \pm 3 \mathrm{~A}$ & $373 \pm 21 \mathrm{~A}$ \\
\hline LA & $30 \pm 1 \mathrm{~F}$ & $232 \pm 9 \mathrm{E}$ & LA & $30 \pm 1$ & $232 \pm 9$ \\
\hline
\end{tabular}


Table 2. Basal diameter (BD, $\mathrm{mm}$ ) at planting, diameter at breast height (DBH, mm) after eleven years—with trees too short to record DBH (1.27 $\mathrm{m}$ ) given a DBH of $0 \mathrm{~mm}$-for family and for seedling size class within family. LA indicates locally available seedlings. Means among families for family treatment and within family for size class (family) treatment with the same letters do not differ statistically $(\alpha=0.05)$.

\begin{tabular}{|c|c|c|c|c|c|c|}
\hline Family & $\begin{array}{l}\text { Family BD at } \\
\text { Planting }\end{array}$ & $\begin{array}{l}\text { Family 11th } \\
\text { Year DBH }\end{array}$ & $\begin{array}{c}\text { Size Class } \\
\text { within Family }\end{array}$ & $\begin{array}{l}\text { Size Class BD } \\
\text { at Planting }\end{array}$ & $\begin{array}{l}\% \text { of Seedlings Large } \\
\text { Enough to Record DBH }\end{array}$ & $\begin{array}{c}\text { Size Class 11th Year } \\
\text { DBH-All Living Trees }\end{array}$ \\
\hline \multirow[t]{3}{*}{8} & $8.5 \pm 0.2 \mathrm{AB}$ & $28.0 \pm 4.9 \mathrm{~A}$ & Small & $6.8 \pm 0.5 C$ & 90 & $27.4 \pm 6 \mathrm{~A}$ \\
\hline & & & Average & $8.6 \pm 0.3 \mathrm{~B}$ & 95 & $26.4 \pm 5 \mathrm{~A}$ \\
\hline & & & Large & $10.0 \pm 0.3 \mathrm{~A}$ & 95 & $29.2 \pm 5 \mathrm{~A}$ \\
\hline \multirow[t]{3}{*}{9} & $8.0 \pm 0.1 \mathrm{~B}$ & $18.6 \pm 4.7 \mathrm{BC}$ & Small & $7.0 \pm 0.2 \mathrm{C}$ & 90 & $15.5 \pm 5 \mathrm{~A}$ \\
\hline & & & Average & $8.0 \pm 0.2 \mathrm{~B}$ & 75 & $19.8 \pm 5 \mathrm{~A}$ \\
\hline & & & Large & $9.1 \pm 0.3 \mathrm{~A}$ & 90 & $18.8 \pm 5 \mathrm{~A}$ \\
\hline \multirow[t]{3}{*}{10} & $8.3 \pm 0.1 \mathrm{~B}$ & $19.8 \pm 4.6 \mathrm{~B}$ & Small & $7.1 \pm 0.1 \mathrm{C}$ & 78 & $18.8 \pm 5 \mathrm{~B}$ \\
\hline & & & Average & $8.3 \pm 0.2 \mathrm{~B}$ & 82 & $16.8 \pm 5 \mathrm{~B}$ \\
\hline & & & Large & $9.4 \pm 0.2 \mathrm{~A}$ & 100 & $22.4 \pm 5 \mathrm{~A}$ \\
\hline \multirow[t]{3}{*}{11} & $8.4 \pm 0.1 \mathrm{AB}$ & $19.1 \pm 4.7 \mathrm{BC}$ & Small & $7.0 \pm 0.3 \mathrm{C}$ & 77 & $12.7 \pm 5 \mathrm{~B}$ \\
\hline & & & Average & $8.0 \pm 0.3 \mathrm{~B}$ & 96 & $18.2 \pm 5 \mathrm{~B}$ \\
\hline & & & Large & $10.2 \pm 0.2 \mathrm{~A}$ & 95 & $25.1 \pm 5 \mathrm{~A}$ \\
\hline \multirow[t]{3}{*}{12} & $8.4 \pm 0.2 \mathrm{AB}$ & $20.3 \pm 4.8 \mathrm{BC}$ & Small & $6.7 \pm 0.3 C$ & 94 & $17.4 \pm 5 \mathrm{~A}$ \\
\hline & & & Average & $8.6 \pm 0.3 \mathrm{~B}$ & 88 & $18.4 \pm 5 \mathrm{~A}$ \\
\hline & & & Large & $9.8 \pm 0.3 \mathrm{~A}$ & 100 & $23.8 \pm 5 \mathrm{~A}$ \\
\hline \multirow[t]{3}{*}{14} & $8.0 \pm 0.2 \mathrm{~B}$ & $17.6 \pm 4.9 \mathrm{BC}$ & Small & $6.8 \pm 0.3 C$ & 83 & $12.2 \pm 6 \mathrm{~B}$ \\
\hline & & & Average & $7.8 \pm 0.3 \mathrm{~B}$ & 63 & $12.7 \pm 5 \mathrm{~B}$ \\
\hline & & & Large & $9.6 \pm 0.4 \mathrm{~A}$ & 100 & $26.0 \pm 6 \mathrm{~A}$ \\
\hline \multirow[t]{3}{*}{16} & $8.9 \pm 0.2 \mathrm{~A}$ & $26.8 \pm 5 \mathrm{~A}$ & Small & $7.4 \pm 0.5 \mathrm{C}$ & 89 & $22.5 \pm 6 \mathrm{~A}$ \\
\hline & & & Average & $8.6 \pm 0.4 \mathrm{~B}$ & 100 & $28.5 \pm 6 \mathrm{~A}$ \\
\hline & & & Large & $10.7 \pm 0.4 \mathrm{~A}$ & 100 & $28.3 \pm 6 \mathrm{~A}$ \\
\hline LA & $6.7 \pm 0.1 \mathrm{C}$ & $16.5 \pm 4.7 \mathrm{C}$ & LA & $6.7 \pm 0.01$ & 70 & $15.8 \pm 5$ \\
\hline
\end{tabular}




\subsection{Study Area}

This study was established in April, 2005 on the Delaware State Forest in Blooming Grove, PA, USA $\left(41^{\circ} 25^{\prime} \mathrm{N}, 75^{\circ} 03^{\prime} \mathrm{W}\right.$, elevation $\left.420 \mathrm{~m}\right)$. This area represents the glaciated low plateau section province of northeastern Pennsylvania, and is dominated by oaks; primarily white oak (Quercus alba L.), northern red oak and chestnut oak (Q. prinus L.); hickory (Carya spp. Nutt), white pine (Pinus strobus L.), pitch pine (P. rigida Mill.), and red maple. The soils at the site are of the Manlius Series and are characterized as strongly acidic, rocky-silt loam with low soil moisture retention. The stand was clearcut in 1975 as part of a commercial harvest to regenerate oak and other economically desirable hardwood species. Preferential browsing by overabundant white tailed deer inhibited hardwood seedling regeneration and facilitated the establishment of a thick understory of sweet fern (Comptonia peregrina (L.) J.M. Coult) and ericaceous shrubs (primarily Vaccinium spp. L.). An 8-hectare $2.4 \mathrm{~m}$ tall woven-wire deer fence was erected on the site in 2005, prior to planting to protect the experimental material from deer browsing. The fence was removed in 2014 once the majority of planted and naturally regenerating seedlings had surpassed deer browse height. Aside from fencing, no other management measures were implemented during the course of the study.

\subsection{Experimental Design}

Seedlings were planted in two replicate plots approximately $150 \mathrm{~m}$ apart. Within each plot, seedlings were planted in an incomplete block design with four seedlings in each block: one small, one average, and one large size class from ten possible families grown following Kormanik et al.'s protocols [30] (therefore each block contained seedlings from multiple families), and one locally available seedling. There were between 10 and 73 seedlings within each size class (family) treatment, and 271 seedlings from the locally available treatment used in the study. The locally available seedlings were included to compare seedlings available at state tree nurseries in the northeast with seedlings grown under advanced nursery protocol designed specifically to yield high quality oak seedlings [30] (the half-sibling seedlings). A total of 1067 seedlings were planted in a $2.4 \mathrm{~m} \times 2.4 \mathrm{~m}$ grid on each of the experimental sites between 12 and 13 April 2005. Three families with a total of 116 seedlings were excluded from the analysis due to low replication across seedling size classes, therefore 951 seedlings from seven families and one bulked seed lot (the locally available seedlings) were included in this study. Seedlings were hand planted using a Jim Gem KBC@ bar, modified by adding $5 \mathrm{~cm}$ to each side of the $30 \mathrm{~cm}$ long blade, creating a blade $15 \mathrm{~cm}$ wide at the top, tapering to the tip.

\subsection{Measurements}

Height and root collar diameter of half-sibling seedlings were measured just after lifting. Height and ground level diameter of the seedlings from the locally available seedlings were measured directly following planting due to the timing of seedling availability. The term basal diameter (BD) is used to describe these baseline diameter measurements throughout the rest of the paper. Basal diameter measurements taken on unplanted bare-root seedlings may be larger than those taken on planted seedlings [37], which in this study may have slightly inflated BD at planting for half-sibling seedlings. Heights of all planted oaks were measured after bud set in 2005-2009, 2011, 2013, and 2015 and diameter at breast height (DBH) was measured following bud set in 2015. All height measurements were taken to the nearest centimeter and diameter measurements to the nearest tenth of a millimeter.

To characterize competing vegetation, a $2.6 \mathrm{~m}$ diameter competition plot was centered on each planted oak seedling and species, height and diameter of the tallest woody competitor within each plot was recorded in late $2015[24,38]$. This size plot was chosen because it approximates the space that a dominant or co-dominant tree occupies at crown closure [39]. Presence of stem forking at or below DBH was recorded in October, 2017. 


\subsection{Statistical Analysis}

All analyses for this study were processed using SAS 9.3 software (SAS Institute 2011, Cary, NC, USA). Analysis of variance was used to detect differences among families and seedling size classes within family for initial height and basal diameter. A repeated-measures, linear mixed-model analysis of variance (LMM) with an autoregressive covariance structure was used to test the fixed effects of family (the bulked seed lot used for the locally available seedlings is considered one family for analysis), size class nested within family, year, and year interactions with family and size (family) on total tree heights for each year (2005-2009, 2011, 2013 and 2015). LMM was also used to evaluate the effects of family and size class within family on 2015 DBH. A DBH of ' 0 ' was scored for seedlings that were shorter than $1.37 \mathrm{~m}$, the height at which DBH is taken. Stem forking at or below DBH (presence/absence) $(p<0.0001)$ was used as a covariate. Generalized LMM with binomial distribution was used to analyze 2015 survival $(1=$ alive, $0=$ dead) and dominance probability of the seedlings. Surviving seedlings that attained at least 80 percent of the height of the tallest competitor within the competition plot were defined as dominant $[21,23,24,40]$. Data were checked for homogeneity of variance and normality. Least-significant-difference tests were performed to identify differences among means $(\alpha=0.05)$.

Rank correlations were used to evaluate the relationship between initial basal diameter and height each year it was measured, and correlation coefficients were squared to be expressed as R-square values. Logistic regression (Proc Logistic) was used to develop models, as previously described by Hosmer and Lemeshow [41], to study influences on eleventh-year (2015) survival and dominance probabilities. Initial height and basal diameter, family and size class were used as explanatory variables, as well as species of tallest competitor for dominance. Multiple regression was used to explain DBH in 2015 using the same variables, as well as height and DBH of the tallest competing woody stem. The log transformation of planted seedling height and DBH of the tallest competing woody stem were used to linearize relationships, however, untransformed values are reported in the tables. The most parsimonious model with the lowest corrected Akaike information criterion value was selected for each dependent variable. The Hosmer-Lemeshow goodness-of-fit statistic was used to test that the model adequately explained the data.

Height growth patterns over the length of the study were derived using quadratic regression for each seedling. Negative, positive, and zero slopes created nine different growth patterns, three linear patterns by three quadratic patterns. For example, a +Linear-Quadratic would indicate a seedling with positive growth but decreasing growth rate over time. Contingency tables were then used to compare the frequency of growth patterns across families and seedling size groups. To highlight differences, groups were pooled when no differences were found.

\section{Results}

\subsection{Seedling Grading}

Seedling height and basal diameter at the time of planting differed among families $(p<0.0001$ for both, $F=72.58$ and 29.51, respectively, Tables 1 and 2$)$ and seedling size classes within family ( $p<0.0001$ for both, $F=16.12$ and 25.39, respectively, Tables 1 and 2). Basal diameter at the time of planting differed among each size class for all families. Height was generally greater in the large size class than average or small for each family. The average size class was larger in height than the small size class in four of the seven half-sibling families. The locally available seedlings were similar in basal diameter to the small size class for all families and were shorter in height than small size class seedlings for all families except one (8).

\subsection{Survival}

After eleven years, sixty-eight percent of the planted oak trees were alive, with significant differences in survival among families $(p<0.0001, F=8.10$, Figure 1$)$, but not among size classes 
within family ( $p=0.1265, F=1.71$ ). Survival in 2015 ranged from forty-six percent for the locally available seedlings to ninety-three percent for family 8 (Figure 1). The logistic regression model that best explained 2015 survival included basal diameter at planting and family (Table 3, Figure 2). The max re-scaled R-square (adjusted to reach a maximum value of 1 ) value for this model was 0.20. Across families, the larger the seedling was at planting, the greater probability that it survived. A seedling that was $7.8 \mathrm{~mm}$ in $\mathrm{BD}$ at planting (the mean BD at planting) from family 8 had an 89 percent chance of survival in 2015, compared with 52 percent for a seedling of the same size from the locally available treatment (Figure 2). Two families (12 and 14) had survival rates similar to the locally available seedlings, lower than all other families, with the greatest mortality occurring in year 2 (Figure 1).

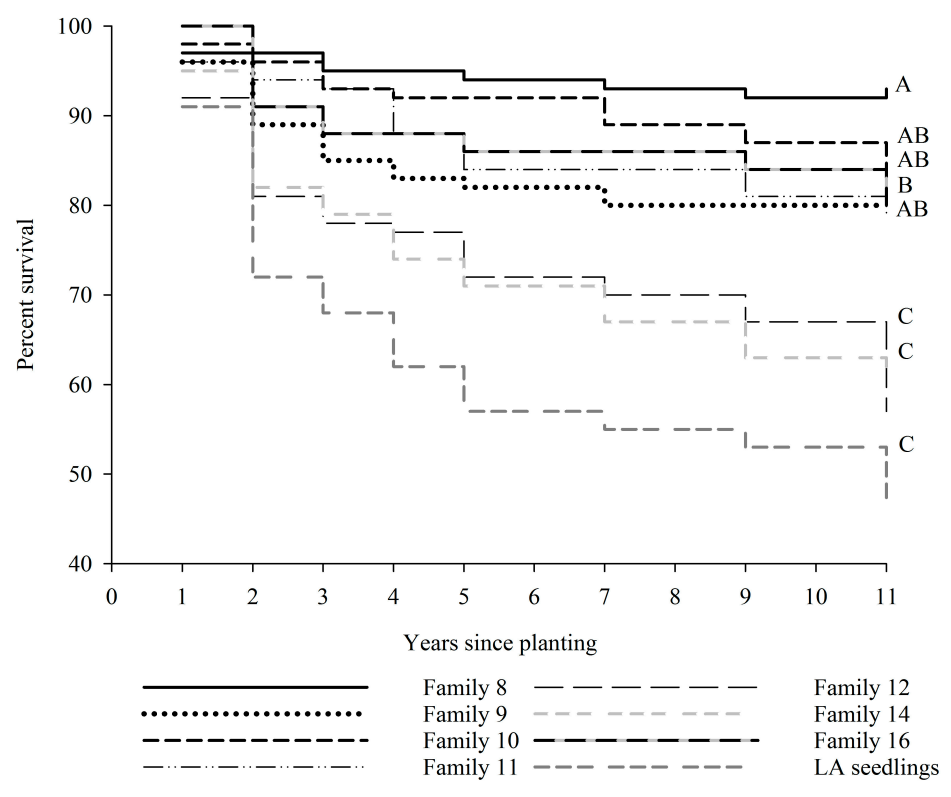

Figure 1. Mean survival among families over the 11-year study. Letters indicate differences in eleventh year survival $(\alpha=0.05)$.

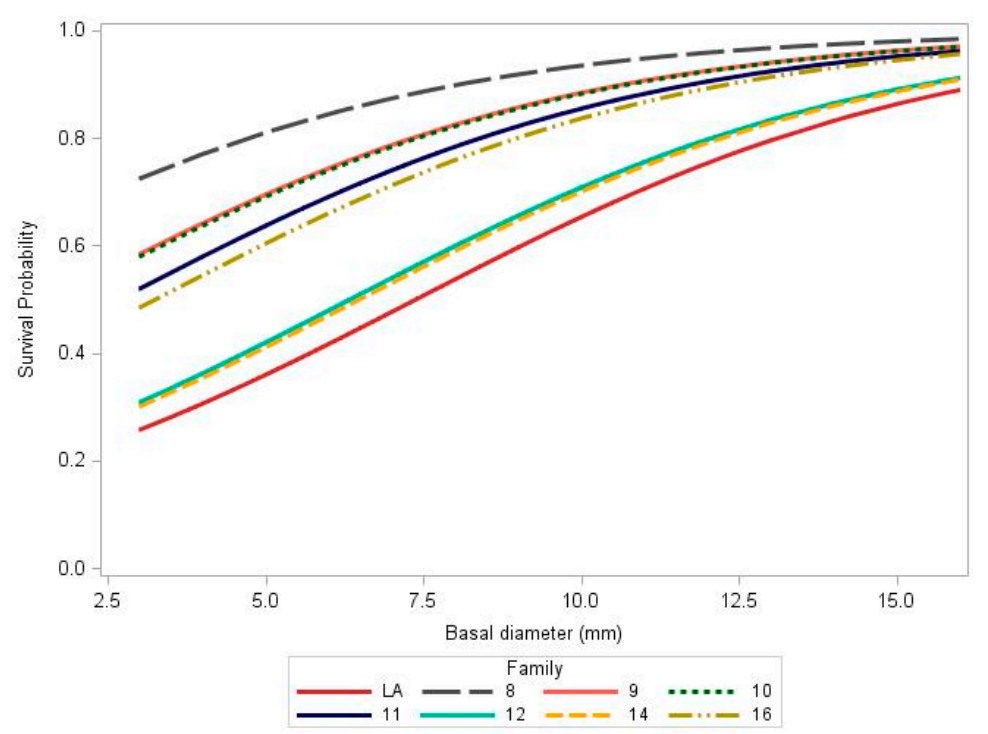

Figure 2. Regression model using family and basal diameter at planting to predict eleventh-year survival. LA indicates locally available seedling treatment. 
Table 3. Coefficients and odds ratio values for regression models to predict survival (logistic regression), diameter at breast height ( $\mathrm{DBH}, \mathrm{mm}$, multiple linear regression), and dominance (logistic regression) of the northern red oak trees eleven years after planting. The locally available seedling treatment (LA) is the reference for the family treatment and planted northern red oak is the reference for species of tallest competitor.

\begin{tabular}{|c|c|c|c|c|c|}
\hline & \multicolumn{2}{|c|}{ Survival } & \multirow{2}{*}{$\begin{array}{c}\text { DBH } \\
\text { Coeff. }\end{array}$} & \multicolumn{2}{|c|}{ Dominance } \\
\hline & Coeff. & OR & & Coeff. & OR \\
\hline $\begin{array}{c}\text { Intercept } \\
\text { Independent variables }\end{array}$ & -0.86 & & & -2.02 & \\
\hline Height at planting $(\mathrm{cm})$ & & & $0.32 * * *$ & & \\
\hline Basal diameter at planting $(\mathrm{mm})$ planting & $0.24^{* * *}$ & 1.27 & & 0.05 & 1.31 \\
\hline $\begin{array}{l}\mathrm{DBH} \text { of tallest competitor }(\mathrm{mm}) \\
\text { Family }\end{array}$ & \multicolumn{4}{|c|}{ Family } & \\
\hline 8 & $1.10 * *$ & 7.59 & $12.16^{* *}$ & & \\
\hline 9 & $0.47 *$ & 4.05 & $5.63 *$ & & \\
\hline 10 & $0.45 *$ & 3.98 & $6.43^{* *}$ & & \\
\hline 11 & 0.21 & 3.12 & 1.41 & & \\
\hline 12 & $-0.67^{* *}$ & 1.29 & $6.61 *$ & & \\
\hline 14 & $-0.71^{* *}$ & 1.41 & 2.70 & & \\
\hline 16 & 0.07 & 2.71 & 6.36 & & \\
\hline \multicolumn{6}{|l|}{ LA (reference) } \\
\hline \multicolumn{6}{|l|}{ Species of tallest competitor } \\
\hline Black cherry & & & & $-1.39 * * *$ & 0.16 \\
\hline Red maple & & & & $-0.51^{* *}$ & 0.38 \\
\hline Serviceberry & & & & 0.45 & 0.98 \\
\hline White oak & & & & $0.89 * *$ & 1.53 \\
\hline Wild northern red oak & & & & 0.18 & 0.75 \\
\hline Other & & & & -0.09 & 0.58 \\
\hline Planted northern red oak (refe & ence) & & & & \\
\hline
\end{tabular}

${ }^{*} p<0.05,{ }^{* *} p<0.01,{ }^{* * *} p<0.0001$.

\subsection{Growth}

The repeated measures height LMM found significant differences among family $(p<0.0001$, $F=14.54$, size class within family $(p=0.0009, F=2.67)$, year $(p<0.0001, F=120.81)$, family by year interaction $(p<0.0001, F=4.70)$, and size class (family) by year interaction $(p<0.0001, F=2.08)$. Families 8 and 16 had the greatest height over the course of the study (406 and $378 \mathrm{~cm}$, respectively after 11 years) and trees from the locally available treatment remained the shortest $(232 \mathrm{~cm}$, Table 1 , Figure 3). We present mean separation only for the height of families and size classes within family at year eleven (Table 1), while all means are displayed in Figure 3. Nearly all size classes were larger in height than seedlings in the locally available treatment after 11 years, except the small and average size classes for one family each (11 and 14, respectively). Large size classes were taller after eleven years than smaller and average size classes in four families, and two families had taller seedlings in the average size class than the small size class. One family (14), exhibited taller seedlings in the small size class than the average size classes.

Basal diameter at planting was positively related to height each year after planting $(p<0.0001$ each year). Squaring the Pearson correlation coefficients produced R-square values of $0.35,0.28,0.24,0.16$, $0.14,0.09,0.10$, and 0.07 , for years 2005-2009, 2011, 2013, and 2015, respectively, exhibiting a relationship that diminished over time until, in year eleven, basal diameter at planting explained less than ten percent of the variation in height.

After eleven years, DBH differed among families and among seedling size classes within family $(p<0.0001$, for each, $F=6.52$ and $F=3.27$, respectively, Table 2). There were no significant interactions between stem fork and eleventh year DBH. The fork was included as a covariate in the LMM model $(p<0.0001)$. Two families (8 and 16) were larger in DBH than the other families, while three families 
$(9,11$ and 14$)$ were similar to the locally available seedling treatment. Trees in the large size class were larger than those in the average and small classes in three families (10, 11 and 14).

The final multiple linear regression model used to explain eleventh-year DBH included initial height, DBH of the tallest competing woody stem, and family (Table 3). Larger DBH of competing stems and larger initial height of the planted seedlings corresponded to greater DBH. On average, an increase in $10 \mathrm{~mm}$ in initial height of a seedlings led to an increase of $3.2 \mathrm{~cm}$ in eleventh-year DBH.

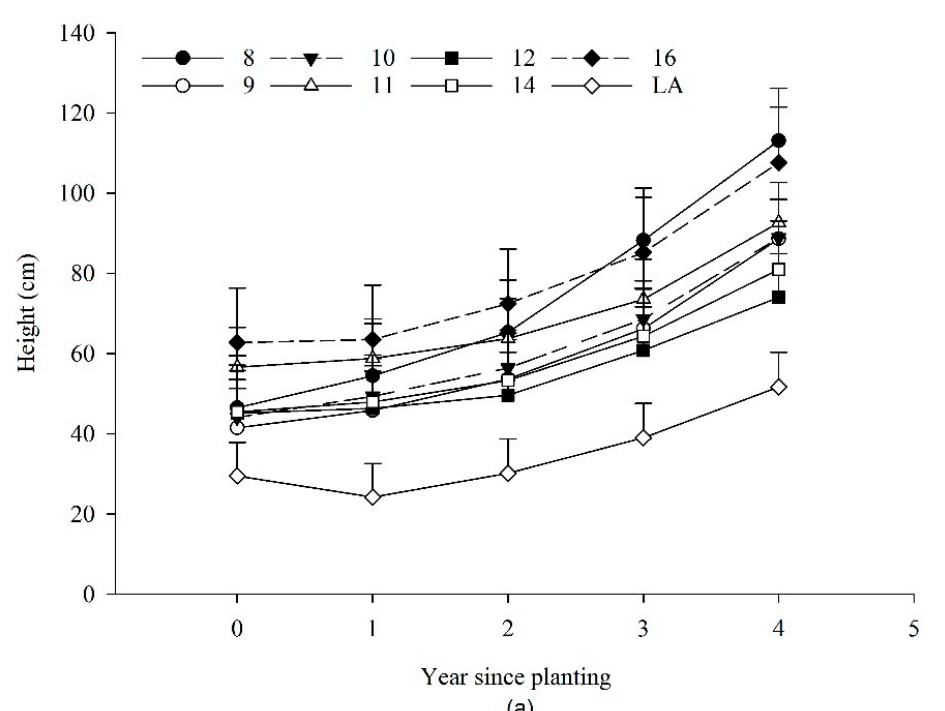

(a)

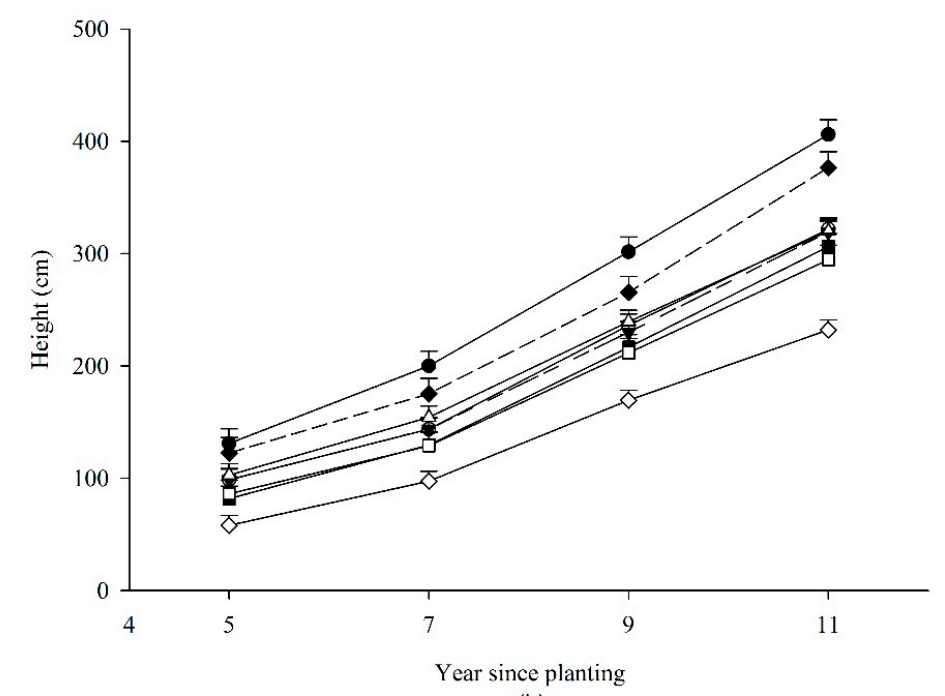

(b)

Figure 3. Height among families for years 0-4 (a) and 5-11 (b). Years are separated into two graphs to improve distinction among lines. Bars indicate standard error. LA indicates locally available seedling treatment.

\subsection{Growth Pattern}

Seedling height growth was described by six equations developed to model growth patterns over the eleven-year study from the nine possible combinations of positive, negative, or absent linear and quadratic terms. Each equation was developed using a minimum of thirty-one trees (Figure 4). PL-0Q (positive linear, no quadratic) and 0L-PQ (no linear, positive quadratic) growth patterns were pooled because there were no differences in frequency of seedlings found in each and both indicated a general positive growth trend over the length of the study. For the analysis evaluating distribution of 
families across the growth patterns, similar families were pooled, creating three family bins (Table 4). Pooling reduced the model chi-square from 116.75 with 35 degrees of freedom to 87.79 with 12 degrees of freedom ( $p<0.0001$ for each). Two families (12 and 14) were pooled with the locally available seedling treatment, four families were pooled into another bin (families 9, 10, 11 and 16), while family 8 remained in its own bin (Table 4). Fifty-five percent of seedlings in family 8 exhibited the PL-PQ growth pattern (steadily increasing growth rate); more than double the amount in the other two bins. Substantially more seedlings in the bin with the locally available seedlings exhibited the $0 \mathrm{~L}-0 \mathrm{Q}$ (mortality or nominal growth) and NL-PQ growth patterns (top dieback, followed by re-sprouting), compared with seedlings in the other bins. For evaluating distribution of seedling size classes across growth patterns, small and average seedlings were similar and therefore pooled. Pooling these size classes and PL-0Q and 0L-PQ growth patterns reduced the model chi-square from 69.23 with 15 degrees of freedom to 56.95 with 8 degrees of freedom. There were significantly more seedlings from the locally available treatment in the $0 \mathrm{~L}-0 \mathrm{Q}$ and fewer seedlings in the PL-PQ growth patterns than the other seedling size classes (Table 5).

Table 4. Frequency table showing growth patterns (depicted in Figure 4) displayed by families over the eleven-year study. LA indicates locally available seedling treatment. Families were pooled when their frequency across growth patterns did not differ, according to chi-square values. The percent of seedlings per group and chi-square value of each cell are listed. The overall chi-square value of the table is $87.79(p<0.0001)$ with twelve degrees of freedom.

\begin{tabular}{|c|c|c|c|c|c|}
\hline \multirow[t]{2}{*}{ Growth Pattern } & & \multicolumn{4}{|c|}{ Family } \\
\hline & & 8 & $9,10,11,16$ & 12,14 and LA & Total Seedlings ( $\%)$ \\
\hline 0L-0Q & Percent & 4 & 9 & 19 & 13 \\
\hline Trees died or added little growth & chi-square & 3.50 & $4.19 *$ & $9.25 *$ & \\
\hline NL-PQ & Percent & 8 & 28 & 34 & 29 \\
\hline Trees died back then grew & chi-square & $8.50 *$ & 0.16 & 2.59 & \\
\hline PL-NQ & Percent & 4 & 5 & 9 & 7 \\
\hline Trees grew then died or died back & chi-square & 0.70 & 1.11 & 2.30 & \\
\hline PL-PQ & Percent & 55 & 23 & 10 & 19 \\
\hline Growth rate increased steadily over time & chi-square & $34.32 *$ & 2.47 & $16.73 *$ & \\
\hline 0L-PQ, PL-0Q (pooled) & Percent & 30 & 34 & 29 & 32 \\
\hline No initial growth & chi-square & 0.04 & 0.92 & 1.01 & \\
\hline
\end{tabular}

Asterisks $\left({ }^{*}\right)$ indicates the observed number within a cell differs significantly from expected.

Table 5. Frequency table showing growth patterns (depicted in Figure 4) displayed by seedling size classes over the eleven-year study. LA indicates locally available seedling treatment. Small and average seedling size classes did not differ in frequency across the growth patterns and therefore were pooled. The percent of seedlings per group and chi-square value of each cell are listed. The overall chi-square value of the table is $56.95(p<0.0001)$ with eight degrees of freedom.

\begin{tabular}{cccccc}
\hline Growth Pattern & & Seedling Size Class & \\
\hline 0L-0Q & & Large & Small and Average & LA & Total Seedlings (\%) \\
\hline NL-PQ & Percent & 6 & 11 & 24 & 13 \\
Trees died or added little growth & Chi-square & $6.11^{*}$ & 1.6 & $17.44^{*}$ & 29 \\
Trees died back then grew & Percent & 26 & 29 & 33 & 0.79 \\
PL-NQ & Chi-square & 0.46 & 0.02 & 8 & 7 \\
Trees grew and then died back & Percent & 3 & 8 & 0.77 & 7 \\
PL-PQ & Chi-square & $4.5^{*}$ & 0.6 & $14.98^{*}$ & 19 \\
Growth increased over time & Percent & 27 & 1.2 & 28 & 32 \\
0L-PQ, PL-0Q (pooled) & Percent & 37 & 31 & 0.81 & \\
No initial growth & Chi-square & 1.86 & 0.08 & & \\
\hline
\end{tabular}

Asterisks $\left({ }^{*}\right)$ indicates the observed number within a cell differs significantly from expected. 


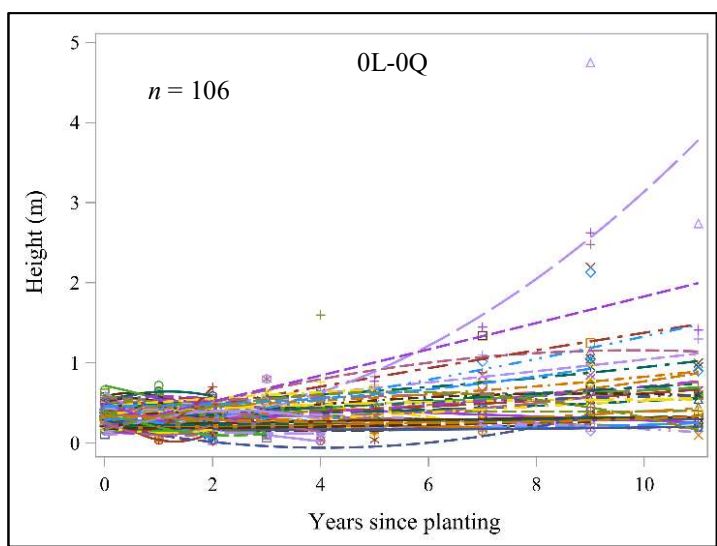

(a)

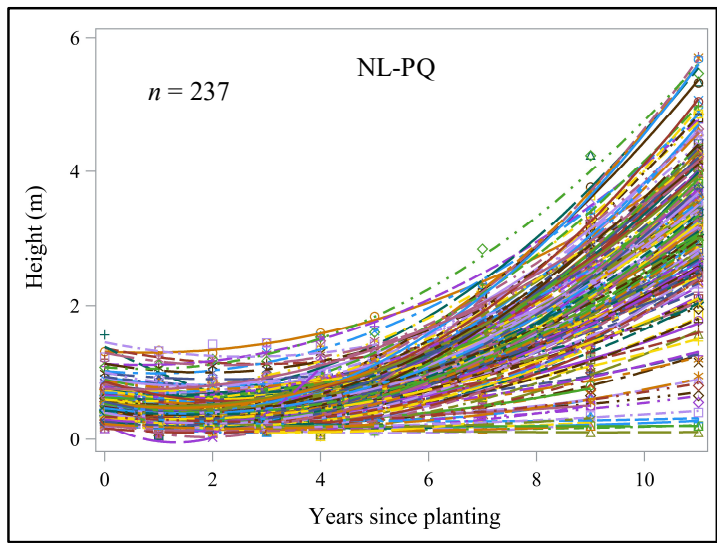

(c)

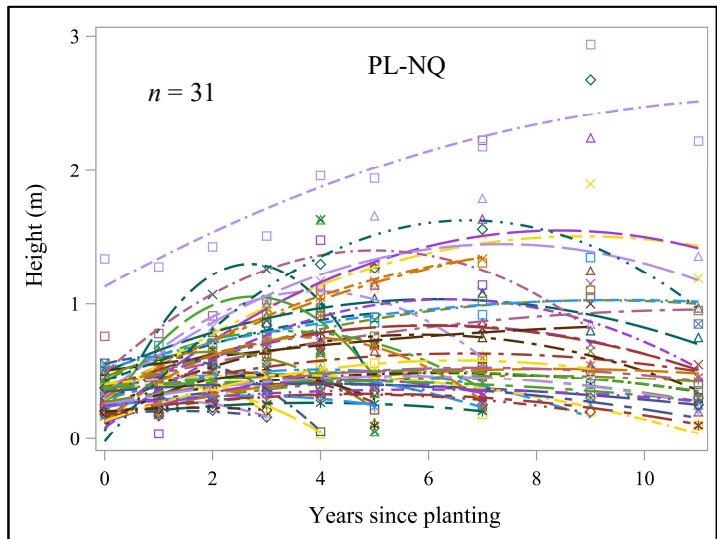

(e)

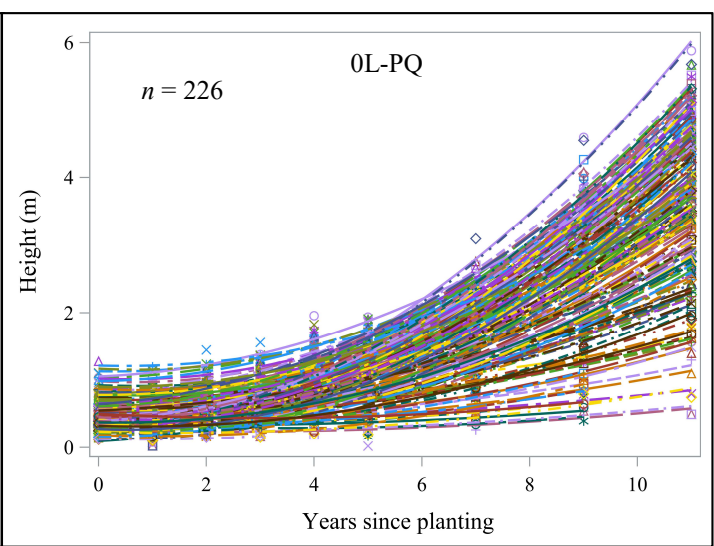

(b)

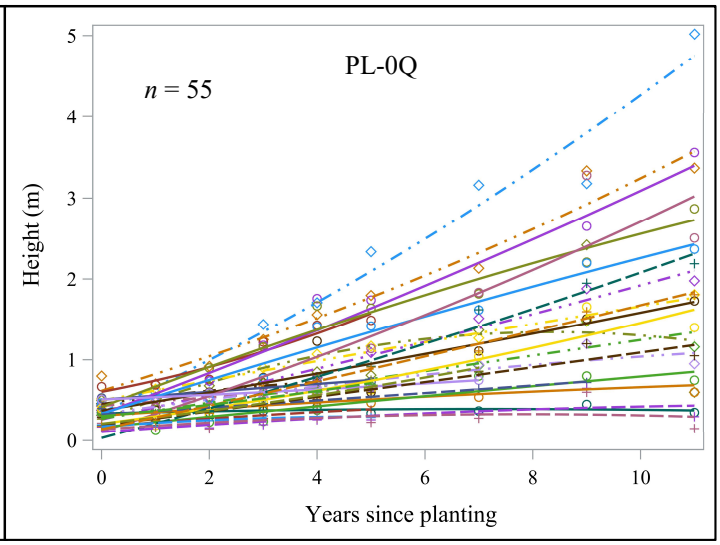

(d)

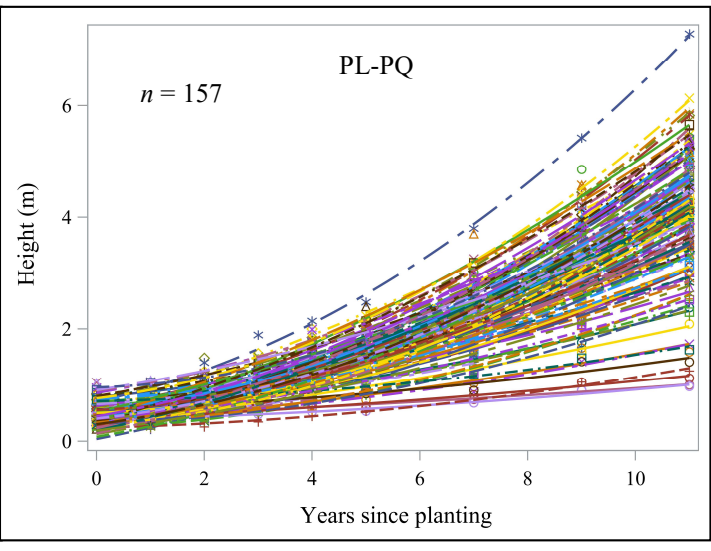

(f)

Figure 4. Linear $(\mathrm{L})$ and quadratic $(\mathrm{Q})$ terms were fit into regression models predicting growth patterns for each seedling. Each term was either not significant (0), or showed a positive $(\mathrm{P})$ or negative $(\mathrm{N})$ trend. Each seedling is represented by a single line within one of six growth patterns. (a) neither the linear nor quadratic terms were significant; seedlings grew nominally; (b) only the quadratic term was significant; seedlings grew slowly and then more rapidly over time; (c) negative linear and positive quadratic terms; seedlings experienced die-back before adding growth; (d) positive linear and no quadratic terms; seedlings grew linearly; (e) positive linear and negative quadratic terms; seedlings grew and then died-back; and (f) positive linear and quadratic terms; seedlings grew progressively more rapidly over time. 


\subsection{Dominance}

Red maple was the tallest woody competitor in twenty-six percent of the competition plots. Serviceberry (Amelanchier spp. Medik.) was the next most abundant tallest competing species (19 percent of plots), followed by black cherry (Prunus serotina, Ehrh., 12 percent), planted northern red oak (11 percent; competition plot diameters were greater than the planting spacing, therefore adjacent planted seedlings were located in competition plots), white oak (9 percent), wild northern red oak (7 percent), and other species (7 percent). Black cherry was the tallest competing species, on average, with a mean height of $562( \pm 19) \mathrm{cm}$ and $47.5( \pm 2.8) \mathrm{mm}$ in DBH, compared to the average height of $321( \pm 6) \mathrm{cm}$ and $\mathrm{DBH}$ of $26.5( \pm 0.5) \mathrm{mm}$ for all planted northern red oak (Figure 5).
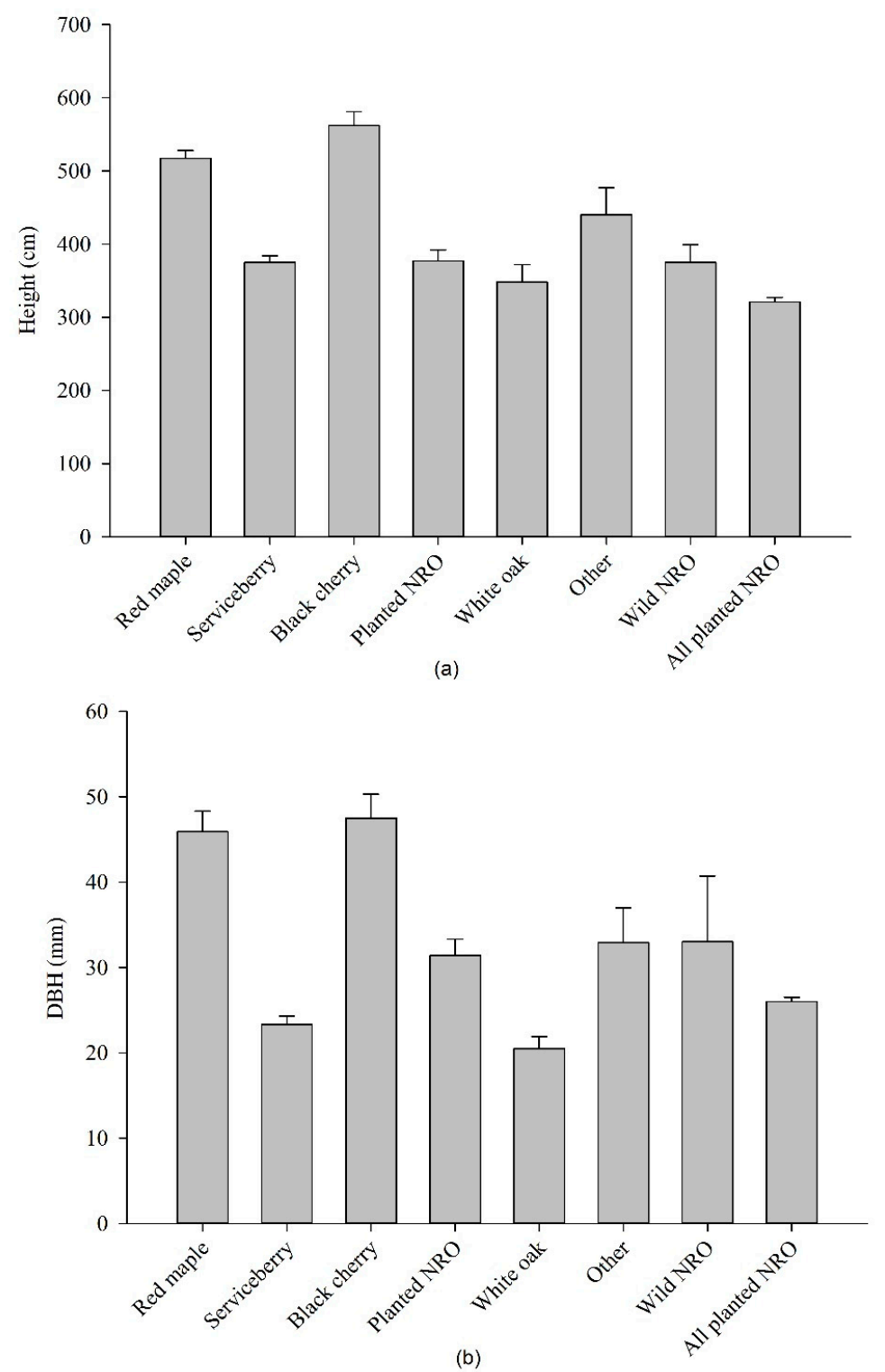

Figure 5. (a) Mean height of tallest woody stem found in competition plots, by species and mean height of the planted northern red oak trees. "Planted NRO" includes only planted northern red oak trees found in competition plots, while "All planted NRO" includes all planted northern red oak; (b) Mean DBH of tallest woody stem found in competition plots, by species and mean DBH of all planted northern red oak. 
Dominance differed among families $(p=0.0086, F=2.83$, Figure 6$)$, but not among seedling size classes ( $p=0.1152, F=1.48$ ). Two half-sibling families, 8 and 16 , had higher dominance than the locally available seedlings, while five were similar (Figure 6). The logistic regression model that best explained dominance included species of tallest competing woody stem and basal diameter at planting, with larger seedlings having a greater chance of being dominant (Table 3, Figure 7). According to the model, which had a max re-scaled R-square value of 0.18 , an oak with a basal diameter of $7.8 \mathrm{~mm}$ at planting (the mean basal diameter at planting) had a 22 percent dominance probability when black cherry was the tallest competing species, compared with a 58 percent chance when a wild northern red oak, 74 percent when a white oak, 41 percent when a red maple, 64 percent when a serviceberry, and 52 percent when another species was the tallest competing stem in the competition plot (Figure 6).

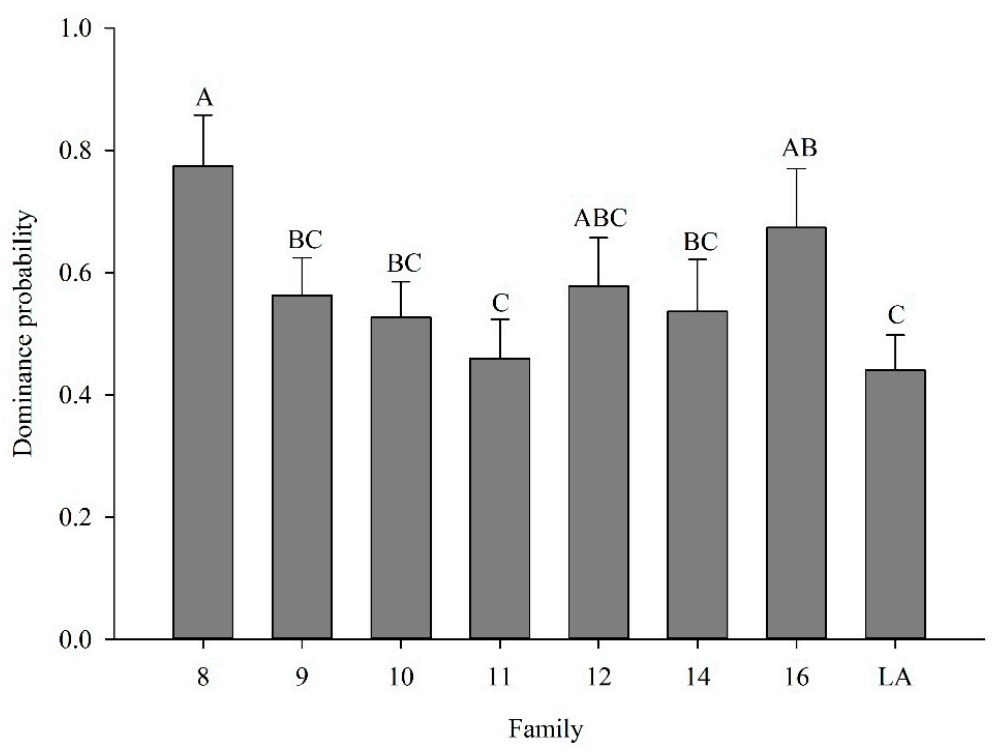

Figure 6. Mean eleventh-year dominance probability ( \pm standard error) among families. Letters indicate significant differences $(\alpha=0.05)$. LA indicates locally available seedling treatment.

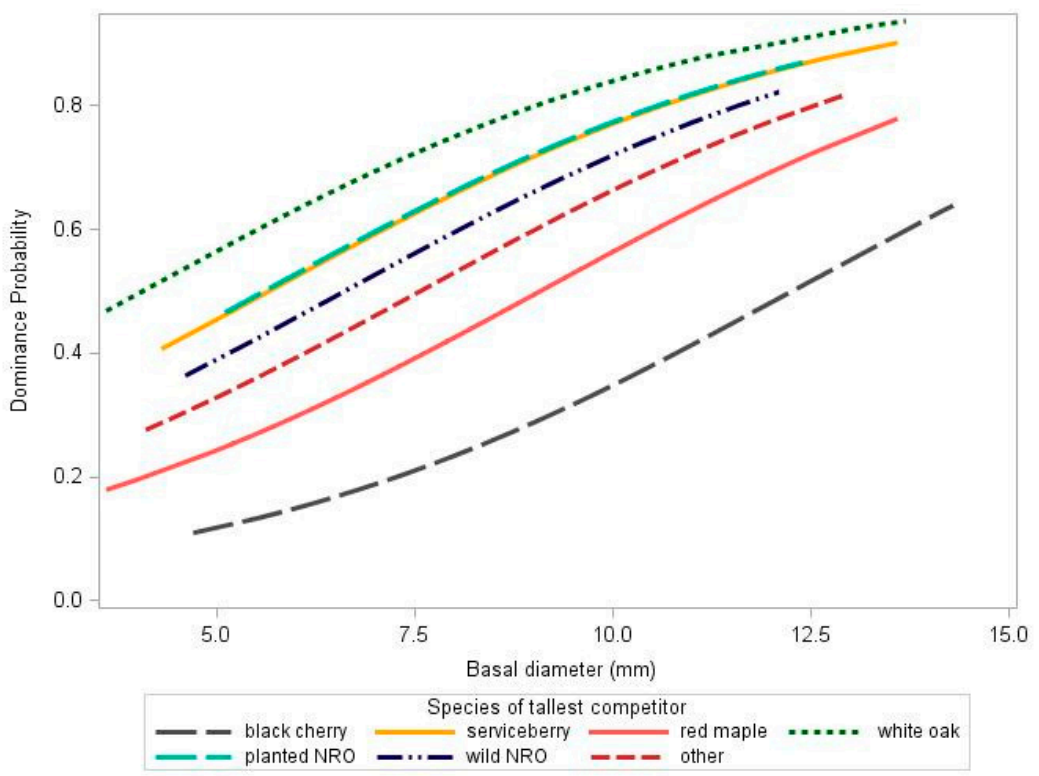

Figure 7. Regression model using basal diameter at planting and species of tallest competing stem to predict eleventh-year dominance probability. NRO stands for northern red oak. 


\section{Discussion}

\subsection{Family}

The results from this eleven year study demonstrate the potential variability in survival, growth, and competitive ability among different northern red oak seed sources. One family (8) consistently showed improved performance across eleventh-year survival, height, $\mathrm{DBH}$, dominance, and growth pattern. By 2015, family 8 was twenty-eight to forty-one percent larger in diameter and ten to thirty-four percent taller on average than the other families (except family 16). Two families (12 and 14) were similar in size to other families at the beginning of the study, but by year eleven, demonstrated inferior growth, survival, and competitive ability. These results show that superior phenotypes in the nursery may not be reflective of subsequent seedling performance, as Kriebel and others have also found [42]. Variation in acorn size among families as well as microsite variation in the nursery-either due to differences in soil or amounts of fertilization and irrigation-may have contributed to initial size differences among families, as families were not replicated in the nursery. Our results demonstrate the substantial variation in seedling performance among families and suggest genetic gains may be achieved through selection of mother trees with desirable phenotypic traits, such as faster juvenile growth. Genetic variation is essential for populations, in terms of adaptation to new stresses such as disease and climate change [43,44], therefore we do not recommend planting seedlings from only several parents. Rather, we do recommend identification of families that demonstrate repeated superior field growth, survival, and competitive ability through the development of tree improvement programs.

\subsection{Seedling Quality}

Size class within family differed in height and DBH for some families but did not affect dominance or survival, according to logistic regression models. Size classes did show differences in growth pattern over the eleven year study, with more locally available seedlings dying or adding little growth than the high-quality seedlings. Most other studies that have evaluated the effect of seedling size class on field performance have followed the seedlings for fewer than ten years [24,27,31,45], with the exception of [28], which evaluated performance 17 years after planting. Clark et al. [24] visually graded northern red oak seedlings into two categories and found, after seven years, that mean height and diameter of seedlings in the larger size class were $40 \mathrm{~cm}$ and $3.8 \mathrm{~mm}$ greater than the small size class, however there were no differences in survival. Ward et al. [45] graded bare-root northern red oak seedlings into four size classes based on the number of first order lateral roots (FOLR), and reported that after seven years, when protected from herbivory using tree shelters, seedlings in the largest class ( $>8$ FOLR) were $82 \mathrm{~cm}$ taller than seedlings in smaller size classes. Zaczek et al. [28] evaluated 10 and 17 year survival and height among twenty stock types, including 1-0 bareroot seedlings, which were comparable in height and basal diameter to the locally available seedlings at planting in this study, and 2-0 bareroot seedlings, comparable to the large size class of the high-quality seedlings used in this study. Survival after 10 years was $44 \%$ for the $1-0$ seedlings, similar to survival of the locally available seedlings in our study, and $77 \%$ for the $2-0$ seedlings. Height after 10 years did not differ between the two stock types. None of these studies included a family treatment in their study; Clark et al. [24] used northern red oak seedlings derived from a single mother tree, Ward et al. [45] did not describe the origin of the seedlings used, and Zaczek $[27,28]$ bulked seeds from four mother trees. While importance of seedling size class to outplanting success in our study was variable, the use of high-quality seedlings produced using improved nursery protocol as compared to seedlings derived from the locally available treatment conferred substantial increases in survival and growth. This suggests that improvements to seedling quality will improve success, but that planting only the very largest seedlings may not impart the same benefits for all families.

While the differences among size classes was variable for the measured traits, seedling size was a significant predictor of eleventh-year survival, DBH growth, and dominance probability. Initial basal 
diameter has consistently been found to be the most important predictor of future growth $[25,46]$ and dominance [15,23]. Most studies followed growth for only one to seven years in the field ([23,28] are exceptions). Our study shows that over time, the relationship between initial diameter and height gradually weakened, similar to what [28] found, presumably due to the effects of other factors. The positive relationship between the $\mathrm{DBH}$ of the tallest competing stem and $\mathrm{DBH}$ of the planted northern red oak, for example, suggests that variation in microsite was an important driver of variation in growth. The importance of initial diameter to early height growth, however, should not be overlooked, as early height growth is vital for seedlings to become established and grow above the deer-browse line quickly.

At planting, seedlings from the locally available treatment were between thirty and fifty percent shorter and fifteen and twenty-five percent smaller in diameter than each of the half-sibling families grown under advanced nursery methods, likely due to differences in nursery protocols. After eleven years, locally available seedlings were still shorter-between twenty-two and thirty-four percent-versus the half-sibling families. They were similar in DBH to four of the seven families, and inferior in dominance probability only to two families (8 and 16). Far more of these seedlings died or grew slowly over the course of the study (24 percent), in comparison to seedlings in most of the half-sibling families (<9 percent, Table 4 ). Few locally available seedlings were large enough to measure DBH after eleven years. The number of families bulked into this seed lot is unknown, therefore, we cannot speculate on the contribution of genetics to field performance. Inferior size at planting undoubtedly played a major role in the poor survival and growth demonstrated by these seedlings. This inferior size can be explained by differences in nursery protocol and conditions; higher seed densities, shorter growing season, and different fertilization and irrigation regimes for the locally available seedling treatment.

\subsection{Competitive Ability}

By the end of the study, 58 percent of living seedlings were dominant. This number is substantially higher than what Morrissey and others [15] found for northern red oak seedlings planted in group selection harvests in Indiana, where only 20 percent of the seedlings were dominant after five years. Fast growing yellow poplar (Liriodendron tulipifera L.), a shade-intolerant species that commonly suppresses oak regeneration [47] was the predominant competitor in that study. Clark and others [24] found that 70 percent of planted northern red oak was dominant in shelterwood harvests after seven years, however competition control in year five likely contributed to the high dominance probability, as only 38 percent of the seedlings were dominant in year three. The xeric nature of our study site likely contributed to the relatively high number of trees that were competitive after eleven years. In our study, dominance was positively related to initial stem diameter, which is similar to what others have found $[15,23,24]$. The species of the tallest competing stem was also a strong predictor of eleven-year dominance, with black cherry posing the greatest challenge to planted oaks. For example, a tree $12 \mathrm{~mm}$ in basal diameter at planting, among the larger used in this study, would only have a thirty three percent chance of being dominant after eleven years when a black cherry was the tallest competitor (Figure 7).

\subsection{Growth Patterns}

We are not aware of any other study that has similarly modeled the individual growth of planted oak growth seedlings over time. A quadratic regression analysis provided the best comprehensive assessment of the eleven-year performance of the planted seedlings. While the LMM height analyses showed how each treatment level, family, or seedling size class, grew over time on average, the growth pattern analysis revealed a more nuanced assessment of growth, by showing the percentage of seedlings within each size class or family that followed certain growth trajectories. For example, far fewer seedlings from families 12 and 14 and the locally available seedling treatment showed a sustained positive growth rate in height over time. Rather, many died, grew slowly, or grew and then died back. However, the LMM analysis found no differences between these and three other 
families $(9,10$ and 11). Likewise, fewer seedlings in the large size class experienced die-back after establishment than those in the smaller size classes and from the locally available seedling treatment, a trend the height LMM analysis was not able to detect. Particularly for multi-year datasets with multiple seedling treatments, this technique provides a comprehensive, more interesting analysis than simply evaluating mean size and survival.

\section{Conclusions}

This study demonstrates the importance of nursery practices and seedling quality to the survival, growth, and competitive ability of northern red oak seedlings planted on a xeric site. After eleven years, the high quality seedlings were taller than the lower quality locally available seedlings. Some families had larger DBH than seedlings from the locally available seedlings, which represented nursery seedlings used for outplantings in the Northeastern U.S. Seedlings in the large size class maintained their size advantage in some, but not all families, demonstrating the variation in growth among families. Overall success by using high-quality seedlings is substantial. While importance of initial size to height diminished over time, it remained an important predictor of eleven-year survival, DBH growth, and dominance. The differences among the half-sibling families show that pedigree can also influence success. The use of quadratic equations to model individual tree growth identified patterns of growth that may be characteristic of families or seedling size, enabling better choice of planting material.

Author Contributions: S.E.S., T.J.H., A.M.S. and J.K.B. conceived and designed the experiments; S.E.S., T.J.H. and C.C.P. performed the experiments, A.M.S. and C.C.P. analyzed the data, and C.C.P. wrote the paper.

Acknowledgments: We thank Christopher Prey, U.S. Military Academy Reservation for assistance with collection of acorns. We acknowledge Tim Dugan, District Forester of Delaware State Forest, PA and Tim Lander, District Forester of Weisler State Forest, PA, for their assistance with the establishment and monitoring of this study. We thank Fengyou Jia, Entomologist, Division of Forest Health, PA Bureau of Forestry, for technical assistance and data collection. Stacy Clark and Mark Coggeshall each provided useful edits to earlier versions of this manuscript. Resources for this study was provided by the USDA Forest Service, Northern Research Station, The Tennessee Tree Improvement Program, and The Pennsylvania Bureau of Forestry.

Conflicts of Interest: The authors declare no conflict of interest.

\section{References}

1. Aszalós, R.; Horváth, F.; Mázsa, K.; Ódor, P.; Lengyel, A.; Kovács, G.; Bölöni, J. First signs of old-growth structure and composition of an oak forest after four decades of abandonment. Biologia (Bratisl) 2017, 72, 1264-1274. [CrossRef]

2. Fei, S.; Kong, N.; Steiner, K.C.; Moser, W.K.; Steiner, E.B. Change in oak abundance in the eastern United States from 1980 to 2008. For. Ecol. Manag. 2011, 262, 1370-1377. [CrossRef]

3. Abrams, M.D. Where has all the White Oak gone? Bioscience 2003, 53, 927-939. [CrossRef]

4. Crow, T.R. Reproductive mode and mechanisms for of northern red oak (Quercus rubra)—A review. For. Sci. 1988, 34, 19-40.

5. Rooney, T.P.; Waller, D.M. Direct and indirect effects of white-tailed deer in forest ecosystems. For. Ecol. Manag. 2003, 181, 165-176. [CrossRef]

6. Abrams, M.D. Fire and the Development of Oak Forests. Bioscience 1992, 42, 346-353. [CrossRef]

7. Nowacki, G.J.; Abrams, M.D. The Demise of Fire and "Mesophication" of Forests in the Eastern United States. Bioscience 2008, 58, 123-138. [CrossRef]

8. Campbell, A.J.; Steiner, K.C.; Finley, J.J.; Leites, L. Limitations on regeneration potential after even-aged harvests in mixed-oak stands. For. Sci. 2015, 61, 874-881. [CrossRef]

9. Steiner, K.C.; Finley, J.C.; Gould, P.; Fei, S.; McDill, M. Oak Regeneration Guidelines for the Central Appalachians. North. J. Appl. For. 2008, 25, 5-16.

10. Dey, D.C.; Jacobs, D.; McNabb, K.; Miller, G.; Baldwin, V.; Foster, G. Artificial Regeneration of Major Oak (Quercus) Species in the Eastern United States-A Review of the Literature. For. Sci. 2008, 54, 77-106. 
11. Brose, P.; Van Lear, D.; Cooper, R. Using shelterwood harvests and prescribed fire to regenerate oak stands on productive upland sites. For. Ecol. Manag. 1999, 113, 125-141. [CrossRef]

12. Miller, G.W.; Brose, P.H.; Gottschalk, K.W. Advanced Oak Seedling Development as Influenced by Shelterwood Treatments, Competition Control, Deer Fencing, and Prescribed Fire. J. For. 2017, 115, 179-189. [CrossRef]

13. Clark, F.B.; Watt, R.F. Silvicultural Methods for Regenerating Oaks. In Proceedings of the Oak Symposium, Upper Darby, PA, USA, 16-20 August 1971; pp. 37-42.

14. Loftis, D.L. Predicting post-harvest performance of advance red oak reproduction in the Southern Appalachians. For. Sci. 1990, 36, 908-916.

15. Morrissey, R.C.; Jacobs, D.F.; Davis, A.S.; Rathfon, R.A. Survival and competitiveness of Quercus rubra regeneration associated with planting stocktype and harvest opening intensity. New For. 2010, 40, $273-287$. [CrossRef]

16. Schuler, J.L.; Robison, D.J. Performance of northern red oak enrichment plantings in naturally regenerating Southern Appalachian hardwood stands. New For. 2010, 40, 119-130. [CrossRef]

17. Struve, D.K.; Joly, R.J. Transplanted red oak seedlings mediate transplant shock by reducing leaf surface area and altering carbon allocation. Can. J. For. Res. 1992, 22, 1441-1448. [CrossRef]

18. Buckley, D.S.; Sharik, T.L.; Isebrands, J.G. Regeneration of northern red oak: Positive and negative effects of competitor removal. Ecology 1998, 79, 65-78. [CrossRef]

19. Ponder, F., Jr. Shoot and root growth of northern red oak planted in forest openings and protected by treeshelters. North. J. Appl. For. 1995, 12, 36-42.

20. Schlarbaum, S.E.; Kormanik, P.; Tibbs, T. Oak Seedlings: Quality Improved Available Now- Genetically Improved Available Soon. In Proceedings of the 25th Annual Hardwood Symposium, Cashiers, NC, USA, 7-10 May 1997; pp. 123-130.

21. Johnson, P.S.; Rogers, R. A method for estimating the contribution of planted hardwoods to future stocking. For. Sci. 1985, 31, 883-891.

22. Dey, D.C.; Parker, W.C. Morphological indicators of stock quality and field performance of red oak (Quercus rubra L.) seedlings underplanted in a central Ontario shelterwood. New For. 1997, 14, 145-156. [CrossRef]

23. Spetich, M.A.; Dey, D.C.; Johnson, P.S.; Graney, D.L. Competitive capacity of Quercus rubra L. planted in Arkansas' Boston Mountains. For. Sci. 2002, 48, 504-517.

24. Clark, S.L.; Schlarbaum, S.E.; Schweitzer, C.J. Effects of visual grading on northern red oak (Quercus rubra L.) seedlings planted in two shelterwood stands on the Cumberland Plateau of Tennessee, USA. Forests 2015, 6, 3779-3798. [CrossRef]

25. Davis, A.S.; Jacobs, D.F. Quantifying root system quality of nursery seedlings and relationship to outplanting performance. New For. 2005, 30, 295-311. [CrossRef]

26. Kormanik, P.P.; Sung, S.S.; Kormanik, T.L.; Zarnock, S.J.; Kormanik, P.P.; Oak, S.J.; Why, R. Oak Regeneration—Why Big Is Better. 1995, pp. 1-9. Available online: https://www.researchgate.net/profile/Shi_ Jean_Sung/publication/237609808_Oak_Regeneration_Why_Big_Is_Better/links/542b29970cf29bbc126a800b / Oak-Regeneration-Why-Big-Is-Better.pdf (accessed on 1 September 2017).

27. Zaczek, J.J.; Steiner, K.C.; Bowersox, T.W. Northern red oak planting stock: 6-year results. New For. 1997, 13, 177-191. [CrossRef]

28. Zaczek, J.J.; Steiner, K.C. The influence of cultural treatments on the long-term survival and growth of planted Quercus rubra. In Proceedings of the 17th Central Hardwood Forest Conference, Lexington, KY, USA, 5-7 April 2010; pp. 294-305.

29. Sander, I.L. Height growth of new oak sprouts depends on size of advance reproduction. J. For. 1971, 69, 809-811.

30. Kormanik, P.P.; Sung, S.-J.S.; Kormanik, T.L. Toward a single nursery protocol for oak seedlings. In Proceedings of the 22nd Southern Forest Tree Improvement Conference, Atlanta, GA, USA, 14-17 June 1993; pp. 89-98.

31. Oswalt, C.M.; Clatterbuck, W.K.; Houston, A.E. Impacts of deer herbivory and visual grading on the early performance of high-quality oak planting stock in Tennessee, USA. For. Ecol. Manag. 2006, 229, 128-135. [CrossRef]

32. Kormanik, P.P.; Sung, S.-J.S.; Kass, D.J.; Schlarbaum, S. Effect of Seedling Size and First-Order-Lateral Roots on Early Development of Northern Red Oak on Mesic Sites. In Proceedings of the Ninth Biennial Southern Silvicultural Research Conference, Clemson, SC, USA, 25-27 February 1997; pp. 247-252. 
33. Gregory, J.; Nowacki, M.D.A. Community, edaphic, and historical analysis of mixed oak forests of the Ridge and Valley Province in central Pennsylvania. Can. J. For. Res. 1991, 22, 790-800.

34. Clark, S.L.; Schlarbaum, S.E.; Keyser, T.L.; Schweitzer, C.J.; Spetich, M.A.; Simon, D.; Warburton, G.S. Response of planted northern red oak seedlings to regeneration harvesting, midstory removal, and prescribed burning. In Proceedings of the 18th Biennial Southern Silvicultural Research Conference; e-Gen. Tech. Rep. SRS-212; U.S. Department of Agriculture, Forest Service, Southern Research Station: Asheville, NC, USA, 2016; p. 8.

35. Clark, S.L.; Schlarbaum, S.E.; Kormanik, P.P. Visual grading and quality of 1-0 northern red oak seedlings. South. J. Appl. For. 2000, 24, 93-97.

36. Johnson, P.S. Responses of planted northern red oak to three overstory treatments. Can. J. For. Res. 1984, 14, 536-542. [CrossRef]

37. Clark, S.; Schweitzer, C.; Schlarbaum, S. Nursery quality and first-year response of American chestnut (Castanea dentata) seedlings planted in the southeastern United States. Tree Plant. Notes 2010, 53, 13-21.

38. Pinchot, C.C.; Schlarbaum, S.E.; Clark, S.L.; Saxton, A.M.; Sharp, A.M.; Schweitzer, C.J.; Hebard, F.V. Growth, survival, and competitive ability of chestnut (Castanea Mill.) seedlings planted across a gradient of light levels. New For. 2017, 48, 491-512. [CrossRef]

39. Sander, I.L.; Johnson, P.S.; Rogers, R. Oak Advance Reproduction in the Missouri Ozarks; North Central Forest Experiment Station, Forest Service, US Department of Agriculture: St. Paul, MN, USA, 1984.

40. Weigel, D.R. Oak planting success varies among ecoregions in the Central Hardwood Region. In Proceedings of the 12th Central Hardwood Forest Conference, Lexington, KY, USA, 28 February-2 March 1999; pp. 9-16.

41. Hosmer, D.W., Jr.; Lemeshow, S.; Sturdivant, R.X. Applied Logistic Regression, 3rd ed.; John Wiley \& Sons: Honoken, NJ, USA, 2013.

42. Kriebel, H.B.; Merritt, C.; Stadt, T. Genetics of growth rate in Quercus rubra: Provenance and family effects by the early third decade in the North Central U.S.A. Silvae Genet. 1988, 37, 193-198.

43. Kitzmiller, J.H. Managing genetic diversity in a tree improvement program. For. Ecol. Manag. 1990, 35, 131-149. [CrossRef]

44. Johnson, R.; Lipow, S. Compatibility of Breeding for Increased Wood Production and Long-Term Sustainability: The Genetic Variation of Seed Orchard Seed and Associated Risks. United States Department of Agriculture Forest Service General Technical Report PNW. 2002, Volume 563, pp. 169-179. Available online: https:/ / www.researchgate.net/profile/Randy_Johnson6/publication/237262080_Compatibility_of_breeding_ for_increased_wood_production_and_long-term_sustainability_The_genetic_variation_of_seed_orchard_ seed_and_associated_risks/links/53e012e50cf2aede4b4cbb24.pdf (accessed on 1 September 2017).

45. Ward, J.S.; Gent, M.P.N.; Stephens, G.R. Effects of planting stock quality and browse protection-type on height growth of northern red oak and eastern white pine. For. Ecol. Manag. 2000, 127, 205-216. [CrossRef]

46. Parker, W.C.; Dey, D.C. Influence of overstory density on ecophysiology of red oak (Quercus rubra) and sugar maple (Acer saccharum) seedlings in central Ontario shelterwoods. Tree Physiol. 2008, 28, 797-804. [CrossRef] [PubMed]

47. Loftis, D.L. Regenerating southern Appalachian mixed hardwood stands with the shelterwood method. South. J. Appl. For. 1983, 7, 212-217.

(C) 2018 by the authors. Licensee MDPI, Basel, Switzerland. This article is an open access article distributed under the terms and conditions of the Creative Commons Attribution (CC BY) license (http://creativecommons.org/licenses/by/4.0/). 